\title{
Do Japanese Firms Price Discriminate in North America?
}

\author{
Gary R. Saxonhouse
}

\section{MEASURING THE IMPACT OF FTAS IN THE WESTERN HEMISPHERE}

QINCE the early 1980s, there has been a continuing, energetic and 2 sophisticated effort to assess the economic consequences of the Canadian-US Free Trade Agreement (CUSTA) and the North American Free Trade Agreement (NAFTA). ${ }^{1}$ This work has been conducted both in an academic setting, in government and in private sector consulting firms. The most interesting of these studies have employed computable general equilibrium (CGE) models to characterise the US, Canadian and Mexican economies and their interrelationships. The dimensions specified in these models typically include a number of industrial sectors, the form of technology, demand, the clearing of factor markets and goods markets, external relationships and trade policy. Most of these studies find that CUSTA and NAFTA, while having little effect on the United States, can have a significant impact on the structure and operation of the Canadian and Mexican economies.

While much of the CGE research agrees as to conclusions, these findings rest very heavily on how technology, productivity, and most importantly, on how the behaviour of capital is modelled. By any reasonable criterion, much of the modelling in these areas is crudely done. ${ }^{2}$ Moreover, by the standards of sectoral research, these models are highly aggregated and non-tariff trade policy, in particular, is treated at an extremely rudimentary level.

It has not been generally recognised that another tradition of research in international economics might be helpful for evaluating the consequences of trade liberalisation and FTAs. The slow pace of adjustment of exchange rate changes in the 1970s and again in the mid- and late 1980s triggered substantial research efforts which continue today. In empirical work explaining the slow response of

GARY R. SAXONHOUSE is from the Department of Economics, University of Michigan, Ann Arbor, Michigan, USA.

${ }^{1}$ This work is reviewed in Brown (1992) and in Brown, Deardorff and Stern (1992).

2 This finding is discussed in Brown (1992). 
prices to exchange rate changes and the slow response of quantities to the price changes that do take place, special emphasis has been placed on contractual obligations and habit persistence. ${ }^{3}$ The resulting literature asks how long it takes short-run inelasticities of supply and demand to give way to the long-run equilibrium of full pass through of exchange rate changes into prices.

In something of a departure from earlier analyses of the impact of exchange rate changes on trade flows, in recent years there has been considerable focus on the role of market structure in shaping this process. This newer approach suggests that in any given sector, whether exchange rate changes lead to large relative price changes or negligible price changes will depend on such industrial structure considerations as the degree of market concentration, the extent of product homogeneity and substitutability and the relative market shares of domestic and foreign firms. ${ }^{4}$ Even absent long-term contracts and habitual behaviour, strategic behaviour will indicate widely varying price response across industries to exchange rate changes. In contrast with the earlier literature, less than full pass through may be an equilibrium response for many industries.

Because much of this newer literature assumes that firms behave strategically not only by virtue of having market power, but also by being able to segment the market at home and various markets abroad from one another, it can be used to provide a new perspective on the economic impact of the CUSTA and NAFTA. The maintained hypothesis of these so-called pricing-to-market models is that firms can segregate their markets, charging prices that differ by more than the cost of transportation between them. For this kind of market power to be present, it is not sufficient that there be economies of scale and/or product differentiation. Rather, what is critical is the presence of trade barriers between markets. Implicit in the estimation of such models are indirect measures of some of the potential gains at the very detailed sectoral level that might come from FTA sponsored trade and investment liberalisation. Such measures can be found by investigating to what degree, prior to the implementation of the CUSTA, did foreign firms behave as if the Canadian and American markets were substantially segregated from one another? And, more generally, to what degree did foreign firms behave as if all the North American markets were substantially segregated from one another? In the process of learning about North America's external adjustment process, a great deal can be learned about North American trade relations. A hitherto unexamined thread between regional integration and the adjustment process can also be explored. In the next section the conceptual framework for analysing the pricing behaviour of firms in foreign markets will be discussed.

\footnotetext{
${ }^{3}$ See Magee (1973) and Wilson and Takacs (1980).

${ }^{4}$ This approach is stressed in Krugman (1987) and Dornbusch (1987). Among recent empirical studies using this general approach are Feenstra (1987), Froot and Klemperer (1989), Ohno (1989), Marston (1990), Knetter (1992) and Saxonhouse (1993).
} 
This framework is then used to study the behaviour of Japanese firms exporting to each of the North American markets.

\section{THE INTERNATIONAL PRICE DISCRIMINATION MODEL ${ }^{3}$}

In investigating the questions just raised, an explicit framework is necessary. Assume that commodity arbitrage is ineffective such that

$$
\phi_{i} \neq r_{i} \Pi_{i f}
$$

where $\phi_{i}=$ price of good $i$ in the home market in home currency, $\Pi_{i f}=$ price of good $i$ in foreign market $f$ in foreign currency, and $r_{f}=$ exchange rate between home currency and foreign market $f$ currency.

In general, the differences in prices across markets will be determined by the differences in demand conditions across markets and their relationship to the producer's common marginal cost. As is well known, the gap between price in each market (expressed in domestic currency) and the marginal cost will be given by

$$
G_{i}=\frac{D_{i}}{D_{i}-1} ; G_{i f}=\frac{D_{i f}}{D_{i f}-1}
$$

where $D_{i}=$ price elasticity of demand for good $i$ in the domestic market, and $D_{i f}$ $=$ price elasticity of demand for good $i$ in the foreign market.

There are three possibilities for the pass through of exchange rate changes into foreign prices.

\section{a. Full Pass Through}

If the demand curves in domestic and overseas markets have constant price elasticities, relative prices for good $i$ across markets will be invariant. With constant price elasticity of demand curves, in equilibrium, exchange rate changes will always be fully passed through to foreign markets.

\section{b. Less than Full Pass Through}

Less than full pass through of exchange rate changes will occur when demand curves are less convex than the constant elasticity of demand curve. In such cases, the elasticity of demand will vary directly with price changes. In

\footnotetext{
s This section follows the discussions in Krugman (1987), Dornbusch (1987), Marston (1990), Feenstra (1987), Knetter (1992) and Saxonhouse (1993).

(C) Basil Blackwell Ltd. 1994
} 
particular, a fall in price will lower price elasticity and a rise in price will raise it. From (2), it is seen that in this instance a fall (rise) in price will raise (lower) the gap between price and marginal cost.

Under these demand conditions, when the yen appreciates, the price of the good in the foreign market rises and the gap between foreign price and marginal cost must narrow. If marginal costs are constant, the gap between price and marginal cost will remain the same in the domestic market. This is an obvious case of less than full pass through. In this case, pass through will vary across markets inversely with the convexity of the demand curves in price. Alternatively, the more the elasticity of demand varies directly with price, the less pass through will be observed.

\section{c. Greater than Full Pass Through}

By contrast with the case just described, when demand functions are more convex than the constant elasticity of price case, exchange rate changes will lead to greater than full pass through. ${ }^{6}$ In this case, a price increase will make demand less elastic. For example, a yen appreciation by raising the foreign price of a good will increase the gap between the price abroad and marginal cost. Once again, with constant marginal costs, the gap between price and costs at home will remain the same. With yen appreciation, prices in terms of yen for goods abroad will rise relative to the yen price of the same goods at home. In this simple case, yen appreciation may lead to a rush to concede markets abroad in the interest of profits.

\section{d. Cost Factors}

Just as differences in the shape of demand curves are critical for explaining differences in the reaction of foreign markets to exchange rate changes, in this price discrimination framework they are also critical for explaining the influence of other factors on the differences between prices at home and abroad for the same good. For example, in the constant elasticity of demand case, since relative prices are invariant to any kind of change, so, as with exchange rate changes, changes in wages and other cost factors will have no impact. More generally, the same results will hold even if demand curves have variable elasticities, provided they have the same curvature.

In light of the above discussion, and considering that income in domestic and foreign markets can be expected to influence demand at home and abroad,

\footnotetext{
${ }^{6}$ Marston (1990).
} 
equation (3) can be adopted as an explanation of sectoral relative prices or sectoral pass through:

$\log \delta_{i}=\log \frac{\phi_{i}}{r_{f} \Pi_{i f}}=\rho_{1} \log q+\rho_{2} \log \frac{w}{p}+\rho_{3} \log \frac{m}{p}+\rho_{4} \log \lambda+\rho_{5} \log \chi$

where $q=$ real exchange rate, $w / p=$ real wages, $m / p=$ real raw material prices, $\lambda=$ domestic income or domestic activity, and $\chi=$ foreign income or foreign activity.

Note that equation (3) assumes that firms set prices instantaneously in response to changes in the right-hand-side variables. If prices are preset, however, these variations in $\delta_{i}$ may simply reflect unanticipated events such as changes in the exchange rate. To allow for this possibility, and following Marston (1990) and Meese and Rogoff (1988), it is assumed that both $r_{f}$ and $q$ follow random walks. This means (3), with time subscripted by $t$, becomes

$$
\begin{gathered}
\log \delta_{i t}=\theta_{0} \log \left(r_{f t}-r_{f t-1}\right)+\rho_{1} \log q_{t-1}+\rho_{2} E_{t-1} \log \frac{w}{p}+ \\
\rho_{3} E_{t-1} \log \frac{m}{p}+\rho_{4} E_{t-1} \log \lambda_{t}+\rho_{5} E_{t-1} \log \chi_{t}
\end{gathered}
$$

where $E_{t-1}=$ expectation on variable in period $t$ from information available at $t-1$.

Equation (4) indicates that if no strategic pricing behaviour is being employed and the $\rho_{i}=0$, then the impact of exchange rate surprises on $\delta_{i t}$ will be shortlived. In the absence of further changes, after a single period, $\delta_{i}$ will return to its original level. It is equation (4) that will be estimated below to throw new light on the presence of trade barriers in North America. The coefficient $\theta_{0}$ on the change in the nominal exchange rate in equation (4) will indicate whether there is a lag in price setting. Recall the coefficient on the real exchange rate, $\rho_{1}$, will measure the proportion of the real exchange rate change passed through into prices.

\section{e. Data}

Ideally, equation (4) might be estimated for each export line to each economy in the Western Hemisphere from each economy both within and outside the Western Hemisphere. At present data are only available for exporters based in Japan. In particular, the behaviour of Japanese firms exporting to Canada, the United States and Mexico is our focus for analysis in this paper. Studying the pricing behaviour of Japanese firms not only provides considerable insight into North American trade relations, it also helps assess the extent to which Japanese 
firms may benefit from the lack of full economic integration here. In the Fall of 1993, the Clinton Administration has repeatedly claimed that were NAFTA not to pass the US Congress, Japan would be better off. ${ }^{7}$ The research to be reported below can help to assess this claim.

Equation (4) has been estimated for each of 41 product lines. These product line equations have been estimated for each of the North American markets using monthly data from January 1983 to June 1988 . For each of the product lines, the Bank of Japan's wholesale price index for that product is used as the Japanese domestic price. In place of detailed country-specific compatible export price data, unit value indices have been constructed for each product line and each country from the Japan Tariff Association trade data. Admittedly, making use of bilateral unit value indices for relatively narrow, specific product lines in place of authentic price data may introduce a great deal of error into this estimation procedure. Nonetheless, because it is a relative price equation and not an import demand or export supply equation that is being estimated, the problems posed by using such data are not insurmountable. After all, this variable appears only on the left-hand side of all the equations being estimated here. ${ }^{8}$

The one set of data from non-Japanese sources is the monthly production indexes used as the activity variable in equation (4). These indexes have been gathered from the monthly or yearly statistical bulletins of the USA, Canada, Mexico and Japan. ${ }^{9}$ The remaining variables, including the Japanese manufacturing wages, Japanese raw material prices and the bilateral exchange rates, are all readily available. ${ }^{10}$ Finally, in each instance, nominal variables are converted to real variables by deflating with the Japanese wholesale prices index.

\section{ESTIMATION, RESULTS AND CONCLUDING COMMENTS}

Altogether, 123 equations have been estimated with the data just outlined. Each equation is estimated with 66 observations after logarithms of each variable have been first differenced and distributed lags applied. Results of this estimation are presented in Tables 1 and 2.

As indicated, interest should focus on the coefficients on the change in the nominal exchange rate and the coefficients on the level of the real exchange rate. Examining the latter first, 105 out of a possible total of 123 coefficients on the level of the real exchange rate are statistically different from zero. At the level of

7 Golden (1993).

${ }^{8}$ See Froot (1988).

${ }^{9}$ Nihon ginko (1993a).

${ }^{10}$ Nihon ginko (1993b). 
TABLE 1

Statistically Significant Variables by Country in Relative Price Equation (4)

\begin{tabular}{lccc}
\hline & United States & Canada & Mexico \\
\hline $\begin{array}{l}\text { Statistically Significant Price } \\
\text { Setting Lag, } \theta_{0} \neq 0\end{array}$ & 19 & 17 & 21 \\
$\begin{array}{l}\text { Statistically Significant Strategic } \\
\text { Price Setting, } \rho_{1} \neq 0\end{array}$ & 34 & 36 & 35 \\
Other Variables Statistically & & & \\
Significant, $\rho_{2} \neq 0, \rho_{3} \neq 0$, & 20 & 22 & \\
$\rho_{4} \neq 0$ and/or $\rho_{5} \neq 0$ & 5 & 4 & 84 \\
$R^{2} \equiv 0.000-0.333$ & 15 & 17 & 23 \\
$R^{2} \equiv 0.334-0.666$ & 21 & 19 & 20 \\
$R^{2} \equiv 0.667-0.999$ & & & \\
\hline
\end{tabular}

Note: The numbers in each cell refer to the number of equations in which a statistically significant variable with the row heading listed appeared. The last three rows present $R^{2} \mathrm{~s}$ regardless of the level of statistical significance.

the individual foreign markets, these results confirm findings from many studies for aggregated overseas markets. Strategic pricing is a pervasive phenomenon. ${ }^{11}$ Of particular interest here, Japanese exporters exhibit this behaviour in all three North American markets.

Not all the 105 coefficients on the real exchange rate are positive. In 13 cases, this coefficient is negative, illustrating the situation where exchange rate changes are more than passed through into foreign prices. Seven of these cases involve the Mexican market, four the Canadian market and three the American market. These cases may reflect nothing more than the relatively small size of some of the markets being investigated here and the resulting instability of some of the unit value indexes being used as dependent variables.

While strategic pricing is a pervasive phenomenon among Japanese exporters to North America, there are also a significant number of cases where exporters do not exhibit this behaviour and fully pass through exchange rate changes. This full pass through can occur even though there may be significant lags in the resetting of goods prices quoted in yen. At the same time, there may be significant lags in the resetting of goods prices quoted in yen even where there is strategic pricing. Overall, in 55 cases out of 123 , a statistically significant coefficient was found on the change in the nominal exchange rate variable.

\footnotetext{
1 See, for example, Marston (1990) who finds evidence of strategic pricing behaviour by Japanese and American firms by studying firm behaviour in all markets taken together. Unlike Marston, but in common with this paper, Froot (1988), Saxonhouse (1993) and Knetter (1992) find evidence of strategic pricing at the level of the individual foreign market.
} 
TABLE 2

Statistically Significant Variables by Product Line in Relative Price Equation (4)

(1)

Statistically
Significant
Price Setting Lag
$\left(\theta_{0} \neq 0\right)$

(2)

Statistically

Significant Strategic

Price Setting $\left(\rho_{1} \neq 0\right)$
(3)

Other Variables Statistically Significant $\left(\rho_{2} \neq 0, \rho_{3} \neq 0\right.$ $\left(\rho_{2} \neq 0, \rho_{3} \neq 0\right.$
$\rho_{4} \neq 0$ and $/$ or $\left.\rho_{5} \neq 0\right)$

\begin{tabular}{|c|c|c|c|}
\hline Paper and Paper Board & 2 & 2 & 1 \\
\hline Polystyrene & - & 3 & 2 \\
\hline Polyvinyl Chloride Resin & - & 2 & 1 \\
\hline Polyester Resin & - & 1 & 2 \\
\hline Metacrylate Resin & - & 2 & 1 \\
\hline Sheet Glass & 1 & 2 & - \\
\hline Steel Sheet for Pilings & - & 3 & 1 \\
\hline Hot-rolled Wide Steel strips & 1 & 2 & 3 \\
\hline Steel Pipes and Tubes for Piping & 1 & 2 & 2 \\
\hline NC Lathes & 2 & 3 & 1 \\
\hline Milling Machinery & 1 & 3 & 2 \\
\hline Machining Centres & 1 & 3 & - \\
\hline Grinding Machinery & 2 & 2 & - \\
\hline Press Machines & 1 & 3 & 2 \\
\hline Forging Machines & 2 & 3 & 1 \\
\hline Drills & 2 & 2 & 1 \\
\hline Milling Cutters & 2 & 3 & 2 \\
\hline Pneumatic Tools & 1 & 2 & 1 \\
\hline Electronic Cash Registers & 2 & 3 & 2 \\
\hline Copying Machines & 3 & 3 & - \\
\hline Rectifiers & 1 & 2 & 2 \\
\hline Hi-Fi Systems & 3 & 3 & 2 \\
\hline Colour Television Sets & 3 & 3 & 3 \\
\hline Condensers & - & 2 & 2 \\
\hline Magnetic Switches & - & 3 & - \\
\hline Switchboards & 2 & 3 & 3 \\
\hline Motor Vehicle Bulbs & 1 & 1 & 1 \\
\hline Diodes & 1 & 3 & 2 \\
\hline Transistors & 1 & 3 & 1 \\
\hline Integrated Circuits & 1 & 3 & 3 \\
\hline Electric Wire & 2 & 2 & 2 \\
\hline Motorcycles & 3 & 3 & 2 \\
\hline Measuring Instruments & 2 & 2 & 1 \\
\hline Cameras & 3 & 3 & - \\
\hline Spectacles & - & - & 1 \\
\hline Wristwatches & 1 & 2 & 2 \\
\hline Alarm Clocks & 1 & 2 & 2 \\
\hline Tape Decks & 2 & 3 & 3 \\
\hline Video Tape Recorders & 3 & 3 & 3 \\
\hline Electronic Organs & 1 & 3 & 2 \\
\hline Wooden Furniture & - & 3 & 3 \\
\hline
\end{tabular}


TABLE 3

Overseas Market and the Length of the Price-Setting Lag

\begin{tabular}{cccc}
\hline & United States & Canada & Mexico \\
\hline Lag Length (Months) & & & \\
1 & 4 & 3 & 2 \\
2 & 4 & 4 & 4 \\
3 & 6 & 6 & 3 \\
4 & 5 & 4 & 3 \\
5 & 2 & 3 & 3 \\
\hline
\end{tabular}

Tables 3 and 4 group these cases by commodity and country and length of priceresetting lag.

There is more to learn from this study than just that Japanese firms practice strategic price setting behaviour in all their North American markets for almost all the goods in the sample used here. What is of special interest is whether strategic price-setting behaviour varies not just by product lines but also across North American markets. It is this variation that is most likely to be eliminated by NAFTA. What is really of interest here are the following hypotheses:

$\mathrm{H}_{1}$ Strategic price setting behaviour does not vary across the American, Mexican and Canadian markets

$$
\rho_{A_{1}}=\rho_{C_{1}}=\rho_{M_{1}}
$$

$\mathrm{H}_{2}$ Strategic price setting behaviour differs between each of the North American markets

$$
\rho_{A_{1}} \neq \rho_{C_{1}} \neq \rho_{M_{1}} \text {. }
$$

$\mathrm{H}_{3}$ Strategic price setting behaviour is the same in Canada and Mexico, but differs between those countries and the United States

$$
\rho_{M_{1}}=\rho_{C_{1}} \neq \rho_{A_{1}} \text {. }
$$

$\mathrm{H}_{4}$ Strategic price setting behaviour is the same in the United States and Mexico, but differs between those countries and Canada

$$
\rho_{M_{1}}=\rho_{A_{1}} \neq \rho_{C_{1}} \text {. }
$$

$\mathrm{H}_{5} \quad$ Strategic price setting behaviour is the same in the United States and Canada, but differs between those countries and Mexico

$$
\rho_{A_{1}}=\rho_{C_{1}} \neq \rho_{M_{1}} \text {. }
$$

Each of these hypotheses embodies a separate model and these models can be compared pairwise. This is a model selection problem and the best-performing model in each pairwise comparison can be selected using likelihood dominance 
TABLE 4

Product and Length of Price Re-Setting Lag

\begin{tabular}{|c|c|c|c|c|c|}
\hline Lag Length (Months) & 1 & 2 & 3 & 4 & 5 \\
\hline Paper and Paper Board & - & - & - & - & 1 \\
\hline Polystyrene & 1 & - & 1 & - & - \\
\hline Polyvinyl Chloride Resin & 1 & - & 1 & - & - \\
\hline Polyester Resin & - & 2 & 1 & - & 一 \\
\hline Metacrylate Resin & - & - & - & 2 & 1 \\
\hline Sheet Glass & - & - & - & 1 & 1 \\
\hline Steel Sheet for Piling & 1 & - & - & - & - \\
\hline Hot-rolled Wide Steel Strips & - & I & 1 & - & - \\
\hline Steel Pipes and Tubes for Piping & - & 1 & - & 1 & - \\
\hline NC Lathes & - & - & - & - & - \\
\hline Milling Machinery & - & - & - & - & - \\
\hline Machining Centres & - & - & 1 & - & - \\
\hline Grinding Machinery & 2 & - & - & - & - \\
\hline Press Machines & - & - & - & - & - \\
\hline Forging Machines & - & - & - & - & - \\
\hline Drills & - & 3 & - & - & - \\
\hline Milling Cutters & - & - & 一 & 2 & 1 \\
\hline Pneumatic Tools & - & - & 1 & 2 & - \\
\hline Electronic Cash Registers & - & - & - & - & - \\
\hline Copying Machines & - & - & - & - & - \\
\hline Rectifiers & 1 & - & & & \\
\hline Hi-Fi Systems & - & - & - & - & - \\
\hline Colour Television Sets & - & - & - & - & - \\
\hline Condensers & - & 1 & 1 & 1 & - \\
\hline Magnetic Switches & - & - & 2 & 1 & - \\
\hline Switchboards & - & - & - & - & 1 \\
\hline Motor Vehicle Bulbs & - & 1 & 1 & 1 & - \\
\hline Diodes & 2 & - & 1 & - & - \\
\hline Transistors & - & - & - & 1 & 2 \\
\hline Integrated Circuits & - & - & 2 & - & - \\
\hline Electric Wire & 1 & 1 & - & 1 & 一 \\
\hline Motorcycles & - & - & - & - & - \\
\hline Measuring Instruments & - & 1 & - & 1 & 1 \\
\hline Cameras & - & - & - & - & - \\
\hline Spectacles & - & - & - & - & - \\
\hline Wristwatches & - & - & - & - & - \\
\hline Alarm Clocks & - & 1 & - & - & - \\
\hline Tape Decks & - & - & - & - & - \\
\hline Video Tape Recorders & - & - & - & - & - \\
\hline Electronic Organs & - & - & - & - & - \\
\hline Wooden Furniture & - & - & - & - & - \\
\hline
\end{tabular}

criteria. ${ }^{12}$ These pairwise comparisons are performed for each of the 41 product lines. The results of this analysis are presented in Table 5 .

${ }_{12}$ This test is discussed in Pollak and Wales (1991). Related tests are discussed in Davidson and Mackinnon (1981) and in Pesaran and Deaton (1978). 


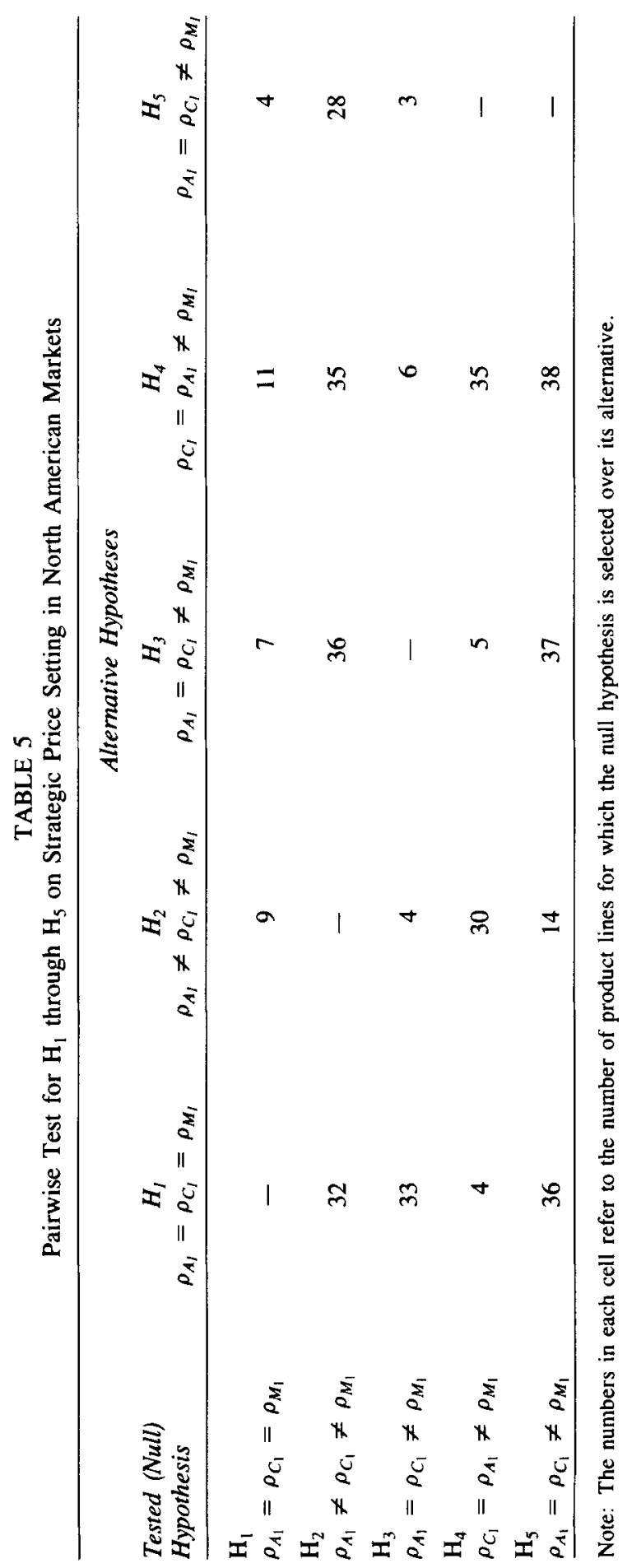


In the pairwise comparisons conducted, for almost all product lines, the hypothesis that there are significant differences in strategic price setting behaviour between each of the North American markets in the 1980s dominates. In light of the CGE results discussed earlier, it is particularly interesting that this hypothesis clearly dominates over the alternative hypothesis that Canadian and American strategic price-setting behaviour was indistinguishable, while their behaviour together is statistically significantly different from Mexican strategic price-setting behaviour. While based on a relatively limited number of product lines and while general equilibrium effects are not considered, the results here are suggestive. Prior to the implementation of the CUSTA and prior to the negotiations about NAFTA, Japanese firms, and presumably firms based in other countries as well, including those based in North America, were able to effectively segregate proximate markets in North America. Significant barriers to commodity arbitrage existed not just between Mexico and the rest of North America, but also between Canada and the United States. These barriers may have been sufficiently important as to affect the global adjustment process. As previous research indicates, removing the barriers which allow Japanese firms and other firms to segregate North American markets from one another should be of tangible benefit to North American welfare ${ }^{13}$ In this sense, the Clinton Administration is correct in suggesting that NAFTA can be beneficial to the United States at Japanese expense. It is just as likely, however, to be beneficial to the United States at the expense of any country whose firms are able to make use of existing intra-North American trade barriers to price discriminate across North American markets.

\section{REFERENCES}

Brown, D. (1992), 'The Impact of a North American Free Trade Area: Applied General Equilibrium Models,' in N. Lustig, B.P. Bosworth and R.Z. Lawrence (eds.), North American Free Trade: Assessing the Impact (Washington, DC: The Brookings Institution).

Brown, D., A. Deardorff and R. Stern (1992), 'North American Integration,' Economic Journal, $102,1507-1518$.

Davidson, R. and J. MacKinnon (1981), 'Several Tests for Model Specification in the Presence of Alternative Hypotheses,' Econometrica, 49, 781-784.

Dorbusch, R. (1987), 'Exchange Rate Changes and Prices,' American Economic Review, 77, $93-106$.

Feenstra, R. (1987), 'Symmetric Pass-Through of Tariffs and Exchange Rates under Imperfect Competition,' National Bureau of Economic Research Working Paper No. 2453.

Froot, K. (1988), 'The Adjustment of the US and Japanese External Imbalances,' Papers and Proceedings of the Fourth EPA International Symposium (Tokyo: Economic Planning Agency).

Froot, K. and P. Klemperer (1989), 'Exchange Rate Pass-Through when Market Share Matters,' American Economic Review, 79, 637-654.

${ }^{13}$ Saxonhouse (1993) finds that Japanese firms also were able to segregate proximate markets in East Asia. 
Golden, T. (1992), ‘Mexican Trade Accord: Japan Role Doubted,' New York Times, 4 November, A6.

Knetter, M. (1992), 'Exchange Rates and Corporate Pricing Strategies,' National Bureau of Economic Research Working Paper No. 4151.

Krugman, P. (1987), 'Pricing to Market when the Exchange Rate Changes,' in S.W. Arndt and J.D. Richardson (eds.), Real and Financial Linkages Among Open Economies (Cambridge, MA: MIT Press).

Magee, S.P. (1975), 'Currency Contracts, Pass-Through and Devaluation,' Brookings Papers in Economic Activity, 1, 303-323.

Marston, R. (1990), 'Pricing to Market in Japanese Manufacturing,' Journal of International Economics, 29, 217-236.

Meese, R. and K. Rogoff (1988), 'Was It Real? The Exchange Rate-Interest Rate Differential over the Modern Floating Period,' Journal of Finance, 43, 933-948.

Nihon ginkō (1993a), Keizai tôkei nempō (Tokyo).

Nihon ginko (1993b), Kokusai hikaku tōkei (Tokyo).

Ohno, K. (1989), 'Export Pricing Behavior in Manufacturing,' International Monetary Fund Staff Papers, 36, 550-579.

Pesaran, M.H. and A.S. Deaton (1978), 'Testing Non-nested, Non-linear Regression Models,' Econometrica, 46, 677-694.

Pollak, R. and T. Wales (1991), 'The Likelihood Dominance Criterion,' Journal of Econometrics, 47, $227-242$.

Saxonhouse, G. (1992), 'Trading Blocs, Pacific Trade and the Pricing Strategies of East Asian Firms,' in J. Frankel and M. Kahler (eds.), Regionalism and Rivalry: Japan and the US in Pacific Trade (Chicago: University of Chicago Press for the National Bureau of Economic Research).

Wilson, J.F. and W. Takacs (1980), 'Expectations and the Adjustment of Trade Flows under Floating Exchange Rates: Leads, Lags and the J-Curve,' International Finance Discussion Paper No. 160 (Washington, DC: Board of Governors of the Federal Reserve System). 
